\title{
Ultrasound-guided Vacuum-assisted Excision of Papillary Breast Lesions as an Alternative to Surgical Excision: 7-year Experience
}

\author{
CM Chau ${ }^{1}$, EPY Fung ${ }^{2}$ CW Wong ${ }^{2}$, KM Kwok ${ }^{2}$, AYH Leung ${ }^{2}$, LKM Wong ${ }^{2}$, KCK Wong², \\ WS Mak', HS Lam², DHY Cho' \\ ${ }^{I}$ Department of Radiology, Princess Margaret Hospital, Hong Kong \\ ${ }^{2}$ Department of Diagnostic and Interventional Radiology, Kwong Wah Hospital, Hong Kong
}

\begin{abstract}
Objective: Removal of papillary breast lesions following percutaneous biopsy is advocated due to their diagnostic challenges. Image-guided vacuum-assisted excision is a treatment option for managing papillary breast lesions. The aim of our study was to review our experience in ultrasound-guided vacuum-assisted excision (US-VAE) of papillary breast lesions.

Methods: This was a retrospective review of patients with biopsy-proven papillary breast lesions who underwent US-VAE from January 2011 to April 2018. The clinical, radiological, and initial biopsy findings and the US-VAE procedure data were collected. The final histology was reviewed for any evidence of malignancy. Patients were followed up by clinical assessment and ultrasound. Lesion excision was considered successful removed if no residual or recurrence was found at follow-up.

Results: A total of 71 patients with 76 papillary lesions underwent US-VAE over a 7-year period. No major complications were observed. The overall cancer upgrade rate on pathology was $5.3 \%$, with cancer upgrade rates for papillary lesions with atypia and without atypia of $16.7 \%$ and $3.1 \%$, respectively. Mean follow-up time was 12.8 months. Two residual lesions were found during follow-up, for a successful lesion removal rate of 97.2\%.

Conclusion: The highly successful lesion removal rate with low residual or recurrence for benign papillary lesions confirms that US-VAE avoids surgical excision in patients with biopsy-proven papillary lesions. It remains a safe and effective alternative to surgical excision in managing biopsy-proven papillary lesions.
\end{abstract}

Key Words: Benign neoplasms/therapy; Breast/surgery; General surgery/instrumentation; Papilloma/therapy; Ultrasonography

\footnotetext{
Correspondence: Dr CM Chau, Department of Radiology, Princess Margaret Hospital, Hong Kong

Email:ccm152@ha.org.hk
}

Submitted: 1 Jan 2019; Accepted: 12 Feb 2019

Contributors: All authors designed the study, acquired the data, analysed the data, drafted the article, and critically revised the article for important intellectual content. All authors had full access to the data, contributed to the study, approved the final version for publication, and take responsibility for its accuracy and integrity.

Conflicts of Interest: All authors have disclosed no conflicts of interest.

Funding/Support: This research received no specific grant from any funding agency in the public, commercial, or not-for-profit sectors.

Ethics Approval: This retrospective study was approved by the Research Ethics Committee of Kowloon Central/Kowloon East Cluster (Ref KC/ KE-18-0128/ER-3). Owing to the retrospective nature of the study, the requirement for informed consent was waived.

Acknowledgement: We thank Ms Ellen LM Yu, Research Officer, Clinical Research Centre, Princess Margaret Hospital, Hong Kong, who advised on the statistical methods for data analysis and assisted in implementing these methods. 


\title{
中文摘要
}

\section{超聲引導真空輔助抽吸乳頭狀乳房病灶切除術作為手術切除的替代方法 : 七年經驗回顧}

\author{
周智敏、馮寶恩、黃鎮威、郭勁明、梁燕霞、黃嘉敏、黃卓琦、麥詠詩、林漢城、曹慶恩 \\ 目的 : 由於診斷上的困難和挑戰, 一般建議經皮活檢診斷的乳頭狀乳房病灶以切除術治療。影像引 \\ 導真空輔助抽吸切除術是乳頭狀乳房病灶的治療方案之一。本研究回顧我院進行超聲引導真空輔助 \\ 抽吸乳頭狀乳房病灶切除術 (US-VAE) 的經驗。 \\ 方法：回顧分析2011年1月至2018年4月期間進行US-VAE的活檢證實乳頭狀乳房病灶患者。收集臨 \\ 床、影像學和初步活檢結果以及US-VAE手術記錄, 核對組織學是否有惡性依據。患者進行臨床評估 \\ 和超聲檢查隨訪。如在隨訪中未發現殘留或復發會被視為已成功切除病灶。 \\ 結果 : 7年內71名患者共76個乳頭狀乳房病灶接受了US-VAE。均無嚴重併發症。總體按照病理結果 \\ 的癌變升級率為 $5.3 \%$, 而具有不典型增生和無不典型增生的乳頭狀病灶的癌變升級率分別為 $16.7 \%$ 和 \\ $3.1 \%$ 。平均隨訪時間為 12.8 個月。在隨訪期間發現兩個殘留病灶。病灶清除成功率為 $97.2 \%$ 。 \\ 結論 : 良性乳頭狀乳房病灶的高成功清除率且低殘留病灶或復發率, 表明對於活檢證實乳頭狀乳房 \\ 病灶患者使用US-VAE可避免手術治療。US-VAE治療活檢證實的乳頭狀乳房病灶是安全有效替代手 \\ 術切除的方案
}

\section{INTRODUCTION}

Papillary breast lesions comprise a broad spectrum ranging from benign papilloma through atypical papilloma or carcinoma in situ to papillary carcinoma, and the distinctions among these lesions represent a continuum that can be difficult to distinguish both radiologically and pathologically. ${ }^{1}$ Together with the underestimation from fine needle aspiration (FNA) and core needle biopsy $(\mathrm{CNB}),{ }^{2-4}$ which are the commonest initial diagnostic procedures for ultrasound-detected breast lesions, this imposes a diagnostic difficulty for papillary breast lesions.

Removal of percutaneously diagnosed papillary lesions is advocated by many studies due to the substantial cancer upgrade rate. ${ }^{5-7}$ However, the drawbacks of surgical excision for all percutaneously diagnosed papillary lesions are the surgical risks, high costs, and long recovery time from surgical operations.

Vacuum-assisted excision has consistently been shown to be effective. ${ }^{8-12}$ The National Health Service (NHS) of the UK has recommended the use of image-guided vacuum-assisted excision to remove benign breast lesions such as fibroadenomas since 2006 and also for management of some histological indeterminate B3 lesions..$^{13,14}$
The aim of our study was to review the outcome and effectiveness of ultrasound-guided vacuum-assisted excision (US-VAE) of papillary breast lesions at our institution.

\section{METHODS}

We reviewed the data of patients that underwent US-VAE in Kwong Wah Hospital from January 2011 to April 2018. Patients with prior biopsy-proven benign papillary lesions were included. We excluded patients with known untreated malignancy in the same breast.

Data on each patient's age at diagnosis, sex, and presenting symptoms were collected from the electronic patient record. The ultrasound characteristics of the lesions, including size and distance from the nipple, were recorded from the ultrasound images or reports. The assessment categories of the lesions were retrieved from the reports. The reporting radiologists were using either the Breast Imaging Reporting and Data System (BI-RADS) by the American College of Radiology or the UK five-point breast imaging classification by the Royal College of Radiologists Breast Group. The initial biopsy methods and their pathology results were collected.

All the US-VAEs were performed by one of five breast radiologists with 2 to 11 years' specialised 
experience in breast imaging. The vacuum-assisted systems used were either EnCor (7-gauge or 10-gauge needle) or Mammotome (8-gauge or 11-gauge needle). The ultrasound images from the biopsy procedure were reviewed, and the lesion identified using a highfrequency linear array ultrasound transducer. A solution of $2 \%$ lidocaine with 1:200000 epinephrine diluted with normal saline in 1:1 ratio (mean $14 \mathrm{~mL}$ ) was injected under the skin and around the lesion as local anaesthesia. The needle was placed underneath the lesion and US-VAE of the lesion was performed with a $180^{\circ}$ sweep (Figure). Complete removal was attempted and evidenced by real-time ultrasound. Any incomplete removal was recorded. A localisation marker was placed at the excision site after lesion removal. Haemostasis was first achieved by manual compression; then the wound was closed with sterile strips followed by a compression dressing around the chest. Any immediate complications during the procedure were recorded. The procedure was performed in an outpatient breast clinic setting and the patient was discharged on the same day after the procedure. Patients were advised to return to our breast clinic if there were any complications, such as breast swelling, bleeding or fever, after the procedure. Major complications were defined as hospitalisation or surgery related to the procedure.

Pathology results from US-VAE were reviewed. Ductal carcinoma in situ (DCIS) and invasive carcinoma were considered as cancer upgrades and were referred for surgical excision. Patients with nonmalignant lesions were followed up by clinical assessment and ultrasound. A lesion was considered as successfully removed if no residual or recurrence was found at follow-up.

Fisher's exact test was used for statistical analysis.

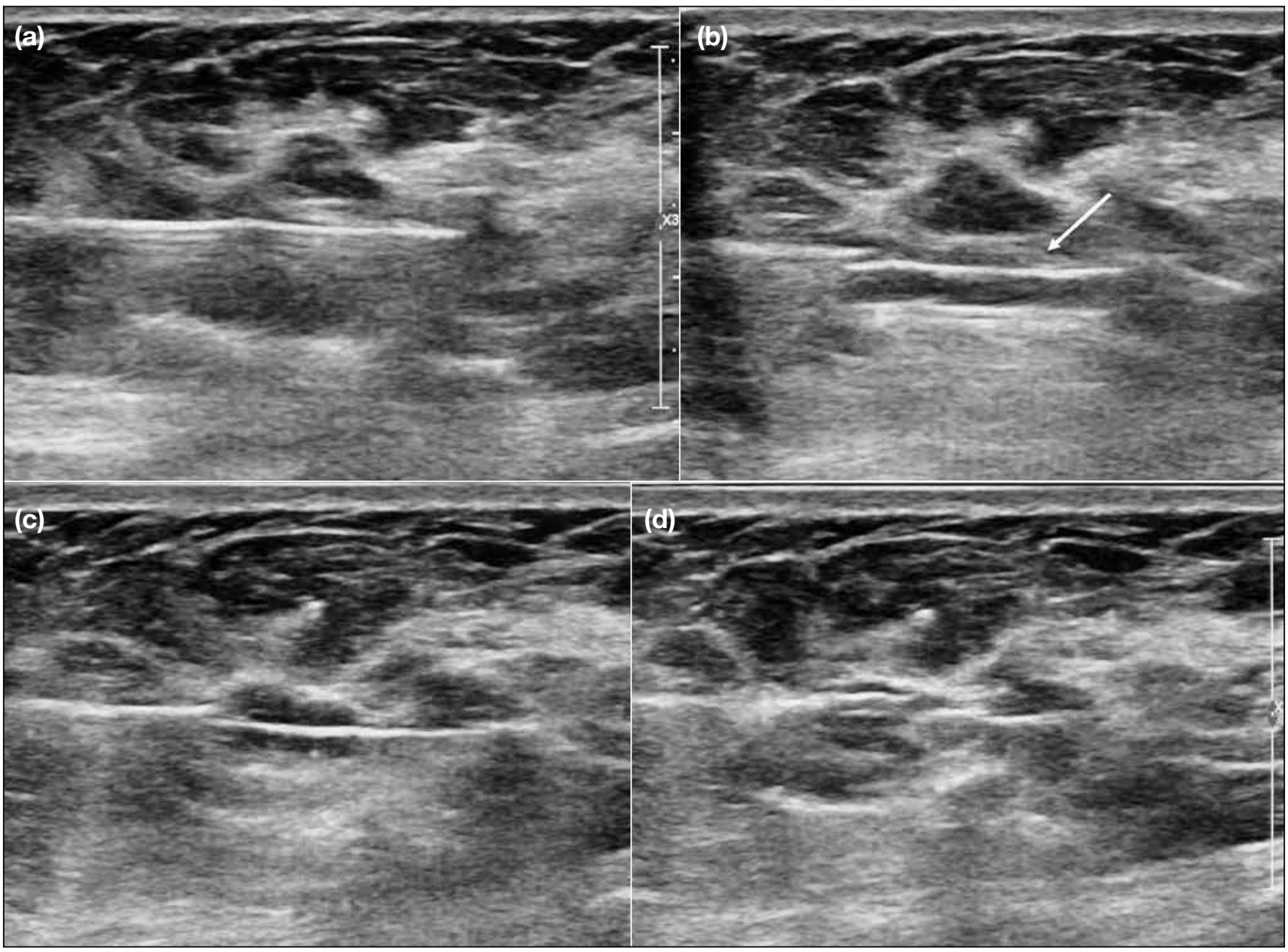

Figure. Ultrasonography images during the ultrasound-guided vacuum-assisted excision (US-VAE) procedure. (a) The needle is placed deep into the lesion. (b) The needle aperture (arrow) is opened to ensure lesion was touching the needle aperture. (c) Real-time ultrasonograph during the VAE procedure showing that the lesion was being sucked into the needle aperture. (d) Ultrasonograph taken to confirm complete removal of the lesion at the end of excision. 


\section{RESULTS}

Between January 2011 and April 2018, of 236 breast lesions in 228 patients removed with US-VAE, there were 77 biopsy-proven papillary breast lesions in 72 patients. One lesion was excluded as the patient had known DCIS in the same breast. In total, there were 76 papillary breast lesions in 71 patients in our study (Table 1).

\section{Clinical, Radiological, and Initial Biopsy Findings of Lesions}

The mean age at presentation was 56.3 years (range, 36-75 years). All were female patients. The majority of the lesions were found during routine screening $(\mathrm{n}=50$, $65.8 \%$ ) or follow-up ultrasound for other breast lesions $(\mathrm{n}=17,22.4 \%)$.

The mean lesion size was $0.81 \mathrm{~cm}$ (range, $0.3 \mathrm{~cm}-2.2 \mathrm{~cm}$ ). The majority of the lesions were $\leq 1.0 \mathrm{~cm}(\mathrm{n}=63,82.9 \%)$ and only one lesion was $>2.0 \mathrm{~cm}$. The recorded locations of the lesions in terms of distance from the nipple were 0 to $4 \mathrm{~cm}$. Subareolar or periareolar lesions were marked as $0 \mathrm{~cm}$ from nipple. There was no indication of the location in five lesions.

The assessment category of each lesion was assigned by the radiologist that performed the initial diagnostic ultrasound before the biopsy. A total of 71 lesions were categorised according to BI-RADS. Five lesions were categorised as R3 (indeterminate/probably benign findings; $\mathrm{n}=2$ ) or R4 (findings suspicious of malignancy; $\mathrm{n}=3$ ), according to the UK five-point breast imaging classification. We had mapped the UK five-point breast imaging classification to BI-RADS according to the study by Taylor et al. ${ }^{15}$ The overall lesion assessment categories are listed in Table 1 . The majority of the lesions were categorised as BI-RADS $4(n=63,82.9 \%)$.

All the papillary lesions had undergone prior ultrasoundguided biopsy, either by FNA, CNB, or both, depending on the operator's preference. The needle sizes and the number of samples are summarised in Table 2. The number of samples obtained from one lesion biopsied with a 10-gauge needle was not specified. All the pathology results from initial biopsy showed papillary lesions. The lesions were further categorised as with or without atypia. If there was a discrepancy between the FNA and CNB pathology results, the lesions were categorised based on the more suspicious pathology. A total of $12(15.8 \%)$ showed atypia and $64(84.2 \%)$ did not have atypia. Seven lesions biopsied with both FNA
Table 1. Clinical, radiological and initial biopsy findings of the lesions $(n=76)$.*

\begin{tabular}{|c|c|}
\hline \multicolumn{2}{|l|}{ Age, y } \\
\hline$\leq 40$ & $3(3.9 \%)$ \\
\hline $41-50$ & $18(23.7 \%)$ \\
\hline $51-60$ & 25 (32.9\%) \\
\hline$>60$ & 30 (39.5\%) \\
\hline \multicolumn{2}{|l|}{ Reason for ultrasound } \\
\hline Screening & $50(65.8 \%)$ \\
\hline Nipple discharge & $4(5.3 \%)$ \\
\hline Follow-up ultrasound & $17(22.4 \%)$ \\
\hline Palpable mass & $4(5.3 \%)$ \\
\hline Mastalgia & $1(1.3 \%)$ \\
\hline \multicolumn{2}{|l|}{ Radiological findings } \\
\hline Lesion size, mean, cm (range) & $0.81(0.3-2.2)$ \\
\hline$\leq 1.0$ & 63 (82.9\%) \\
\hline$>1.0$ to $\leq 2.0$ & $12(15.8 \%)$ \\
\hline$>2.0$ & $1(1.3 \%)$ \\
\hline \multicolumn{2}{|l|}{ Distance from nipple, cm } \\
\hline 0 & $9(11.8 \%)$ \\
\hline 1 & $21(27.6 \%)$ \\
\hline 2 & $15(19.7 \%)$ \\
\hline 3 & $20(26.3 \%)$ \\
\hline 4 & $6(7.9 \%)$ \\
\hline Not reported & $5(6.6 \%)$ \\
\hline \multicolumn{2}{|l|}{ Assessment category } \\
\hline BI-RADS 3/R2 & 12 (15.8\%) \\
\hline BI-RADS 4/R3 and R4 & $63(82.9 \%)$ \\
\hline BI-RADS 5/R5 & $1(1.3 \%)$ \\
\hline \multicolumn{2}{|l|}{ Initial biopsy findings } \\
\hline \multicolumn{2}{|l|}{ Initial biopsy method } \\
\hline FNAC only & $21(27.6 \%)$ \\
\hline CNB only & $22(28.9 \%)$ \\
\hline Both & 33 (43.4\%) \\
\hline \multicolumn{2}{|l|}{ Initial biopsy result } \\
\hline Papillary lesion with atypia & $12(15.8 \%)$ \\
\hline By FNA & $9(11.8 \%)$ \\
\hline By CNB & 3 (3.9\%) \\
\hline By FNA and CNB & 0 \\
\hline Papillary lesion without atypia & $64(84.2 \%)$ \\
\hline By FNA & $15(19.7 \%)$ \\
\hline By CNB & $22(28.9 \%)$ \\
\hline By FNA and CNB & 27 (35.5\%) \\
\hline
\end{tabular}

Abbreviations: BI-RADS = Breast Imaging Reporting and Data System; CNB = core needle biopsy; FNAC = fine needle aspiration cytology.

* Data are shown as No. (\%) of patients.

Table 2. Summary of ultrasound-guided vacuum-assisted excision needle size, and number of samples $(n=76)$.

\begin{tabular}{lcc}
\hline Needle size & Patients & Samples per patient \\
\hline 7 gauge & $14(18.4 \%)$ & $5.6(4-10)$ \\
8 gauge & $1(1.3 \%)$ & 10 \\
10 gauge & $57(75.0 \%)$ & $6.3(3-20)$ \\
11 gauge & $4(5.3 \%)$ & $7.5(4-13)$ \\
\hline
\end{tabular}

* Data are shown as No. (\%) or mean (range). 
Table 3. Summary table of cancer upgrade lesions.

\begin{tabular}{lcclllll}
\hline $\begin{array}{l}\text { Patient } \\
\text { No. }\end{array}$ & $\begin{array}{c}\text { Age, } \\
\text { y }\end{array}$ & $\begin{array}{l}\text { Size, } \\
\mathrm{cm}\end{array}$ & $\begin{array}{l}\text { Initial biopsy } \\
\text { method }\end{array}$ & $\begin{array}{l}\text { Initial biopsy } \\
\text { pathology }\end{array}$ & VAE pathology & $\begin{array}{l}\text { Subsequent } \\
\text { management }\end{array}$ & Final pathology \\
\hline 1 & 74 & 0.7 & $\begin{array}{l}\text { FNAC and } \\
\text { CNB }\end{array}$ & $\begin{array}{l}\text { Papillary lesion (by } \\
\text { FNAC) } \\
\text { Papillary lesion with } \\
\text { atypical epithelial cell } \\
\text { proliferation (by CNB) }\end{array}$ & Solid papillary carcinoma & Lumpectomy & Papillary carcinoma \\
2 & 53 & 1 & FNAC & $\begin{array}{l}\text { Papillary lesion } \\
\text { DCIS of intermediate grade }\end{array}$ & $\begin{array}{l}\text { Lumpectomy } \\
\text { involving papilloma }\end{array}$ & $\begin{array}{l}\text { Intraductal papilloma and } \\
\text { atypical ductal hyperplasia }\end{array}$ \\
3 & 69 & 1 & FNAC & $\begin{array}{l}\text { Papillary lesion with } \\
\text { atypical feature } \\
\text { Papillary lesion }\end{array}$ & DCIS & Mastectomy & $\begin{array}{l}\text { Intraductal papilloma; } \\
\text { fibrocystic changes; no } \\
\text { residual malignancy }\end{array}$ \\
\hline
\end{tabular}

Abbreviations: CNB = core needle biopsy; DCIS = ductal carcinoma in situ; FNAC = fine needle aspiration cytology; VAE = vacuum-assisted. excision.

and CNB had had discrepant pathology results, in which FNA showed atypia but CNB did not in five lesions and CNB showed atypia but FNA did not in two lesions. Thus, overall there were nine papillary lesions with atypia diagnosed by FNA and three by CNB.

\section{Ultrasound-guided Vacuum-assisted Excision Results}

All the lesions were confirmed as completely removed by ultrasonogram. The sample weight of each lesion was calculated by multiplying the weight of each core ${ }^{16}$ by the number of cores. The mean sample weight for lesions $<1 \mathrm{~cm}$ was $1.345 \mathrm{~g}( \pm 0.530$; range, 0.336-2.904 g) and for lesions $\geq 1 \mathrm{~cm}$ was $1.920 \mathrm{~g}( \pm 1.033$; range, 0.588 $4.420 \mathrm{~g})$.

No major complication was noted during the procedures and no patient returned to the breast clinic for complications after being discharged. One patient required skin sutures due to a laceration during the procedure with uneventful wound healing.

Four malignant lesions were found in three patients from the final pathology of US-VAE. These included one DCIS, two DCIS with papilloma, and one solid papillary carcinoma. The overall cancer upgrade rate was $5.3 \%$. Among the four malignant lesions, three lesions had FNA only and one had FNA and CNB as initial biopsies. Two of them had atypical features on initial biopsy, identified by FNA and CNB (Table 3). Thus, the cancer upgrade rate for papillary lesions with atypia was $16.7 \%$ and that for papillary lesions without atypia was $3.1 \%(\mathrm{p}=0.115)$. The pathologies excised with US-VAE are listed in Table 4.
Table 4. Pathology of ultrasound-guided vacuum-assisted excision $(n=76){ }^{*}$

\begin{tabular}{lc}
\hline & Patients \\
\hline Papilloma & $46(60.5 \%)$ \\
Intraductal papilloma & $41(89.1 \%)$ \\
Atypical intraductal papilloma & $1(2.2 \%)$ \\
Complex sclerosing papilloma & $1(2.2 \%)$ \\
Highly complex papillary apocrine change & $1(2.2 \%)$ \\
Intraductal papilloma with ADH & $2(4.3 \%)$ \\
Other benign lesions & $26(34.2 \%)$ \\
Fibrocystic change & $13(50.0 \%)$ \\
Fibroadenoma & $2(7.7 \%)$ \\
Adenomyoepithelioma & $1(3.8 \%)$ \\
Mammary hamartoma & $1(3.8 \%)$ \\
Sclerosing adenosis & $1(3.8 \%)$ \\
Tubular adenoma & $1(3.8 \%)$ \\
Benign & $7(26.9 \%)$ \\
Malignant & $4(5.3 \%)$ \\
DCIS in papillary lesion & $2(50 \%)$ \\
DCIS & $1(25 \%)$ \\
Solid papillary carcinoma & $1(25 \%)$ \\
\hline
\end{tabular}

Abbreviations: $\mathrm{ADH}$ = atypical ductal hyperplasia; DCIS = ductal carcinoma in situ.

* Data are shown as No. (\%) of patients.

\section{Follow-up}

Four patients had subsequent surgery. The four malignant lesions in three patients were removed with lumpectomy or mastectomy (Table 3). Two patients with DCIS showed no residual malignancy in the final pathology from surgical excision. One benign lesion underwent lumpectomy as the pathology from VAE showed atypical intraductal papilloma. The final pathology from the lumpectomy was benign intraductal papilloma.

The rest of the 67 patients were followed up clinically and $51(76.1 \%)$ patients had follow-up ultrasound. The 
Papillary Lesions: US-Guided Vacuum Excision

Table 5. Summary table of residual lesions.

\begin{tabular}{|c|c|c|c|c|c|c|c|c|c|}
\hline $\begin{array}{l}\text { Patient } \\
\text { No. }\end{array}$ & Age, y & $\begin{array}{l}\text { Size, } \\
\mathrm{cm}\end{array}$ & $\begin{array}{c}\text { Distance } \\
\text { from nipple, } \\
\mathrm{cm}\end{array}$ & $\begin{array}{c}\text { Probe } \\
\text { gauge (G) }\end{array}$ & $\begin{array}{l}\text { No. of } \\
\text { samples }\end{array}$ & $\begin{array}{l}\text { VAE } \\
\text { pathology }\end{array}$ & $\begin{array}{l}\text { Detection of } \\
\text { residual lesion }\end{array}$ & $\begin{array}{l}\text { Subsequent } \\
\text { management }\end{array}$ & Final pathology \\
\hline 4 & 60 & 0.5 & 1 & 10 & 6 & $\begin{array}{l}\text { Intraductal } \\
\text { papilloma }\end{array}$ & $\begin{array}{l}\text { Follow-up } \\
\text { ultrasound }\end{array}$ & Lumpectomy & $\begin{array}{l}\text { Benign intraductal } \\
\text { papilloma }\end{array}$ \\
\hline 5 & 46 & 1.5 & 2 & 7 & 7 & $\begin{array}{l}\text { Intraductal } \\
\text { papilloma }\end{array}$ & $\begin{array}{l}\text { Stereotactic } \\
\text { biopsy }\end{array}$ & No further action & $\begin{array}{l}\text { Residual benign } \\
\text { intraductal papilloma }\end{array}$ \\
\hline
\end{tabular}

Abbreviation: VAE = vacuum-assisted excision.

mean follow-up time was 12.8 months (range, 1.367.4 months). The overall rate of successful lesion removal was $97.2 \%$. Table 5 shows the handling of residual pathology in two patients.

Lesion size, location, and probe gauge were not statistically significant predictors of residual lesions.

\section{DISCUSSION}

Management of percutaneously diagnosed papillary lesions has been a challenge for years due to its diagnostic difficulty and substantial rate of cancer upgrade. The reported cancer upgrade rate has ranged from $3.1 \%$ to $15.8 \%{ }^{5-7}$ and lesion removal was advocated in many different studies..$^{5-7,17-20}$ Before the advent of percutaneous VAE, surgical excision was the treatment of choice for lesion removal. As more and more papillary lesions were diagnosed in breast screening, the high costs of labour and operation theatre time would be a burden to the healthcare system. ${ }^{21}$ Moreover, since the papillary lesions were indeterminate in biopsy histology with chances of being a benign papilloma, patients may be reluctant to undergo surgical excision due to the morbidity and mortality from surgical and anaesthetic risks.

Image-guided VAE was initially used to improve diagnostic accuracy for percutaneous biopsy due to larger cores obtained when compared to conventional FNA and CNB..$^{9,10}$ Its use has been extended to remove benign lesions because a larger amount of tissue can be obtained in one pass, and with better cosmetic results. US-VAE can be performed as an outpatient procedure in the clinic and the patient can be discharged on the same day, resulting in much lower costs than those incurred with surgical excision. ${ }^{22}$

In our series, a success rate of $97.2 \%$ for benign papillary lesion removal by US-VAE without residual or recurrent disease was achieved, in line with the reported overall success rate of $97 \%$ to $100 \%$ in the literature. ${ }^{23,24}$
Two residual lesions were found, which raises the question of how complete removal can be achieved confidently during the procedure. For US-VAE, the only evidence of lesion removal is by real-time ultrasound imaging. However, during the procedure, there are inevitable small haematomas and oedema at the procedure site, ${ }^{25}$ which may obscure the field and make it difficult for the operators to determine whether the lesion is completely removed or not. Some operators remove breast tissue surrounding the lesions at four more sampling sites to ensure complete lesion removal but the results varied. ${ }^{26,27}$ The NHS Breast Screening working group had suggested a specimen of approximately $4 \mathrm{~g}$ to be equivalent to surgical excision. ${ }^{28}$ Also, the working group did not state the size range of the lesion for their recommendation. Smaller lesions can be completely excised with a lower specimen weight.

The two residual lesions in our study occurred at the early stage (2013 and 2014) since we started US-VAE in 2011. Salazar et $\mathrm{al}^{29}$ reported that 11 excisions were required to acquire skills to perform complete excision in more than $80 \%$ at the end of the US-VAE and 18 excisions at 6 months. Thus, operator experience is one of the important factors for successful lesion removal. Centres performing US-VAE should formulate standardised training and credentialing for better performance of US-VAE.

Three papillomas with atypical features were found (Table 4), namely, one atypical intraductal papilloma and two intraductal papillomas with atypical ductal hyperplasia. The atypical intraductal papilloma underwent surgical excision and final pathology showed benign papilloma with no atypical or invasive features. The two intraductal papillomas with ADH had no recurrence or cancer development during the follow-up period of 11.0 months and 27.6 months. The literature shows a low underestimation rate of $0 \%$ with US-VAE. ${ }^{23,30}$ Thus, these lesions can be safely managed 
by close monitoring after multidisciplinary discussion and this approach is supported by the consensus from the UK and Europe. ${ }^{28,31}$

No major complication was found after US-VAE in our series. US-VAE has been reported as a safe procedure with a low rate of complications, ranging from $0 \%$ to 9\%. . $^{10,12,23,24,27,32,33}$ The majority of complications included hematoma and pain, which were usually self-limiting and did not require further intervention. One of our patients required suturing due to skin laceration during the procedure because the lesion was superficially located. This was considered as a minor complication and we should inform patients about this potential complication, especially when the lesion is close to the skin.

In our study, the cancer upgrade rate for papillary lesions diagnosed by FNA or CNB prior to US-guided VAE was $5.3 \%$, which is compatible with the literature. ${ }^{67,18}$ For diagnosing papillary lesions with atypia, pathologists need to assess the size of the area of atypical epithelial proliferation and sometimes it would be difficult to distinguish atypical epithelial proliferation within a papilloma from low-grade DCIS within a papilloma in the tissue samples,$^{34}$ and FNA may miss the small foci of carcinoma in situ or the foci that are invasive. ${ }^{35,36}$ Thus, for papillary lesions with atypia diagnosed by FNA or $\mathrm{CNB}$, surgical excision would be more appropriate as the next step of management, as included in the recommendations from the NHS Breast Screening working group.

There were a few limitations in this study. Our sample size was small, as was the number of residual lesions. Thus, we could not identify any statistically significant factors associated with incomplete excision. Also, the adequate sample weight for different lesion sizes may need further study for validation. There would be selection bias in a retrospective study as the lesion size, location of the lesion and technical factors may affect the clinicians', radiologists' and patients' decision on choosing US-VAE or surgical excision. Only $70.8 \%$ of patients had follow-up ultrasonography examination, which may have resulted in underestimation of the residual rate.

In conclusion, our successful lesion removal rate with low rates of residual or recurrence for benign papillary lesions confirms that US-VAE spares most patients with FNA- or CNB-proven papillary lesions from surgical excision and provides adequate tissue samples for a confident diagnosis guiding subsequent management. It is a safe and effective alternative to surgical excision in managing biopsy-proven papillary lesions.

\section{REFERENCES}

1. Sohn V, Keylock J, Arthurs Z, Wilson A, Herbert G, Perry J, et al. Breast papillomas in the era of percutaneous needle biopsy. Ann Surg Oncol. 2007;14:2979-84.

2. Houssami N, Ciatto S, Ellis I, Ambrogetti D. Underestimation of malignancy of breast core-needle biopsy: concepts and precise overall and category-specific estimates. Cancer. 2007;109:48795.

3. Ciatto S, Houssami N, Ambrogetti D, Bianchi S, Bonardi R, Brancato B, et al. Accuracy and underestimation of malignancy of breast core needle biopsy: the Florence experience of over 4000 consecutive biopsies. Breast Cancer Res Treat. 2007;101:291-7.

4. Youk JH, Kim EK, Kim MJ, Oh KK. Sonographically guided 14-gauge core needle biopsy of breast masses: a review of 2420 cases with long-term follow-up. AJR Am J Roentgenol. 2008;190:202-7.

5. Rizzo M, Linebarger J, Lowe MC, Pan L, Gabram SG, Vasquez L, et al. Management of papillary breast lesions diagnosed on coreneedle biopsy: clinical pathologic and radiologic analysis of 276 cases with surgical follow-up. J Am Coll Surg. 2012;214:280-7.

6. Jaffer S, Nagi C, Bleiweiss IJ. Excision is indicated for intraductal papilloma of the breast diagnosed on core needle biopsy. Cancer. 2009;115:2837-43.

7. Chang JM, Moon WK, Cho N, Han W, Noh DY, Park IA, et al. Management of ultrasonographically detected benign papillomas of the breast at core needle biopsy. AJR Am J Roentgenol. 2011;196:723-9.

8. Rajan S, Shaaban AM, Dall BJ, Sharma N. New patient pathway using vacuum-assisted biopsy reduces diagnostic surgery for B3 lesions. Clin Radiol. 2012;67:244-9.

9. Simon JR, Kalbhen CL, Cooper RA, Flisak ME. Accuracy and complication rates of US-guided vacuum-assisted core breast biopsy: initial results. Radiology. 2000;215:694-7.

10. Cassano E, Urban LA, Pizzamiglio M, Abbate F, Maisonneuve P, Renne $\mathrm{G}$, et al. Ultrasound-guided vacuum-assisted core breast biopsy: experience with 406 cases. Breast Cancer Res Treat. 2007;102:103-10.

11. Chang JM, Han W, Moon WK, Cho N, Noh DY, Park IA, et al. Papillary lesions initially diagnosed at ultrasound-guided vacuumassisted breast biopsy: rate of malignancy based on subsequent surgical excision. Ann Surg Oncol. 2011;18:2506-14.

12. Fine RE, Boyd BA, Whitworth PW, Kim JA, Harness JK, Burak WE. Percutaneous removal of benign breast masses using a vacuum-assisted hand-held device with ultrasound guidance. Am J Surg. 2002;184:332-6.

13. National Institute for Health and Care Excellence, UK Government. Image-guided vacuum-assisted excision biopsy of benign breast lesions. 2006. Available from: https://www.nice.org.uk/guidance/ ipg156/resources/imageguided-vacuumassisted-excision-biopsyof-benign-breast-lesions-pdf-1899863283488965. Accessed 23 Sep 2018

14. National Health Service. NHS Breast Screening Programme. Clinical guidance for breast cancer screening assessment. 2016. Available from: https://associationofbreastsurgery.org. uk/media/1414/nhs-bsp-clinical-guidance-for-breast-cancerscreening-assessment.pdf. Accessed 23 Sep 2018.

15. Taylor K, Britton P, O'Keeffe S, Wallis MG. Quantification of the UK 5-point breast imaging classification and mapping to BI-RADS 
to facilitate comparison with international literature. Br J Radiol. 2011;84:1005-10.

16. Preibsch H, Baur A, Wietek BM, Krämer B, Staebler A, Claussen $\mathrm{CD}$, et al. Vacuum-assisted breast biopsy with 7-gauge, 8-gauge, 9-gauge, 10-gauge, and 11-gauge needles: how many specimens are necessary? Acta Radiologica. 2015;56:1078-84.

17. Mercado CL, Hamele-Bena D, Oken SM, Singer CI, Cangiarella J. Papillary lesions of the breast at percutaneous core-needle biopsy. Radiology. 2006;238:801-8.

18. Sakr R, Rouzier R, Salem C, Antoine M, Chopier J, Daraï E, et al. Risk of breast cancer associated with papilloma. Eur J Surg Oncol. 2008;34:1304-8.

19. Tatarian T, Sokas C, Rufail M, Lazar M, Malhotra S, Palazzo JP, et al. Intraductal papilloma with benign pathology on breast core biopsy: to excise or not? Ann Surg Oncol. 2016;23:2501-7.

20. Leithner D, Kaltenbach B, Hödl P, Möbus V, Brandenbusch V, Falk $S$, et al. Intraductal papilloma without atypia on image-guided breast biopsy: upgrade rates to carcinoma at surgical excision. Breast Care (Basel). 2018;13:364-8.

21. Fernández-García P, Marco-Doménech SF, Lizán-Tudela L, Ibáñez-Gual MV, Navarro-Ballester A, Casanovas-Feliu E. The cost effectiveness of vacuum-assisted versus core-needle versus surgical biopsy of breast lesions. Radiologia. 2017;59:40-6.

22. Alonso-Bartolomé P, Vega-Bolívar A, Torres-Tabanera M, Ortega E, Acebal-Blanco M, Garijo-Ayensa F, et al. Sonographically guided 11-G directional vacuum-assisted breast biopsy as an alternative to surgical excision: utility and cost study in probably benign lesions. Acta Radiol. 2004;45:390-6.

23. Kim MJ, Kim EK, Kwak JY, Son EJ, Park BW, Kim SI, et al. Nonmalignant papillary lesions of the breast at US-guided directional vacuum-assisted removal: a preliminary report. Eur Radiol. 2008;18:1774-83.

24. Ko KH, Jung HK, Youk JH, Lee KP. Potential application of ultrasound-guided vacuum-assisted excision (US-VAE) for wellselected intraductal papillomas of the breast: single-institutional experiences. Ann Surg Oncol. 2012;19:908-13.

25. Fine RE, Whitworth PW, Kim JA, Harness JK, Boyd BA, Burak Jr WE. Low-risk palpable breast masses removed using a vacuum-assisted hand-held device. Am J Surg. 2003;186:362-7.

26. Kim SY, Kim EK, Lee HS, Kim MJ, Yoon JH, Koo JS, et al.
Asymptomatic benign papilloma without atypia diagnosed at ultrasonography-guided 14-gauge core needle biopsy: which subgroup can be managed by observation? Ann Surg Oncol. 2016;23:1860-6.

27. Youk JH, Kim EK, Kwak JY, Son EJ, Park BW, Kim SI. Benign papilloma without atypia diagnosed at US-guided 14-gauge coreneedle biopsy: clinical and US features predictive of upgrade to malignancy. Radiology. 2011;258:81-8.

28. Pinder SE, Shaaban A, Deb R, Desai A, Gandhi A, Lee AH, et al. NHS Breast Screening multidisciplinary working group guidelines for the diagnosis and management of breast lesions of uncertain malignant potential on core biopsy (B3 lesions). Clin Radiol. 2018;73:682-92.

29. Salazar JP, Miranda I, De Torres J, Rus MN, Espinosa-Bravo M, Esgueva A, et al. Percutaneous ultrasound-guided vacuum-assisted excision of benign breast lesions: A learning curve to assess outcomes. Br J Radiol. 2019;92:20180626.

30. Grady I, Gorsuch H, Wilburn-Bailey S. Ultrasound-guided, vacuum-assisted, percutaneous excision of breast lesions: an accurate technique in the diagnosis of atypical ductal hyperplasia. J Am Coll Surg. 2005;201:14-7.

31. Rageth CJ, O'Flynn EA, Comstock C, Kurtz C, Kubik R, Madjar $\mathrm{H}$, et al. First International Consensus Conference on lesions of uncertain malignant potential in the breast (B3 lesions). Breast Cancer Res Treat. 2016;159:203-13.

32. Maxwell AJ. Ultrasound-guided vacuum-assisted excision of breast papillomas: review of 6-years experience. Clin Radiol. 2009;64:801-6.

33. Kim MJ, Park BW, Kim SI, Youk JH, Kwak JY, Moon HJ, et al. Long-term follow-up results for ultrasound-guided vacuum-assisted removal of benign palpable breast mass. Am J Surg. 2010;199:1-7.

34. Page DL, Salhany KE, Jensen RA, Dupont WD. Subsequent breast carcinoma risk after biopsy with atypia in a breast papilloma. Cancer. 1996;78:258-66.

35. Michael CW, Buschmann B. Can true papillary neoplasms of breast and their mimickers be accurately classified by cytology? Cancer. 2002;96:92-100.

36. Gomez-Aracil V, Mayayo E, Azua J, Arraiza A. Papillary neoplasms of the breast: clues in fine needle aspiration cytology. Cytopathology. 2002;13:22-30. 